\title{
SIKAP MAHASISWA TERHADAP MERK LOKAL \\ (Studi pada Mahasiswa Pemakai Produk Kosmetik Sariayu)
}

\author{
Oleh: Tiwi Nurjannati Utami ${ }^{*}$
}

\begin{abstract}
Abstrak
Perusahaan yang ingin bertahan lama di pasar, sebaiknya mengalokasikan biaya untuk pembentukan merek. Hal ini karena dengan memiliki merek yang kuat dan dikenal luas oleh konsumen merupakan investasi jangka panjang bagi perusahaan. Sikap konsumen terhadap merek merupakan salah satu komponen yang perlu diperhatikan perusahaan yang ingin meningkatkan penjualan dan mempertahankan produknya di pasar. Tujuan penelitian ini adalah: (1) untuk mengetahui gambaran sikap konsumen terhadap merek lokal (2) untuk mengetahui hubungan dan pengaruh keyakinan terhadap dukungan mahasiswa pada merek lokal (3) untuk mengetahui hubungan dan pengaruh kesukaan terhadap dukungan mahasiswa pada merek lokal. Penelitian dilakukan terhadap 60 mahasiswa yang menggunakan kosmetik merek lokal Sariayu. Analisis yang digunakan adalah analisis korelasi dan regresi untuk menguji hipotesis.

Berdasarkan hasil uji hipotesis diketahui bahwa kesukaan terhadap merek lokal berhubungan dan berpengaruh positif terhadap dukungan terhadap merek lokal. Serta keyakinan terhadap merek lokal berhubungan dan berpengaruh positif terhadap dukungan terhadap merek lokal.
\end{abstract}

Key words: Keunggulan kompetitif, merk lokal, investasi jangka panjang

\section{PENDAHULUAN}

\section{Latar Belakang Masalah}

Dalam pemasaran modern, setiap perusahaan dituntut berupaya menciptakan keunggulan kompetitif yang berkesinambungan dalam menghadapi semakin banyak munculnya pemain baru (pesaing) yang bergerak dalam industri yang sama atau barang substitusi. 
Merek memegang peranan yang signifikan bagi kemajuan perusahaan. Merek bukanlah sekedar nama yang menempel pada produk. Dalam kondisi banyak produk dan derasnya informasi seperti saat ini, konsumen pertama kali akan mengingat merek produk, bukan produsennya. Merek berbeda dengan produk. Produk hanyalah sesuatu yang dihasilkan pabrik, sedangkan merek merupakan sesuatu yang dibeli konsumen. Bila produk bisa dengan mudah ditiru oleh pesaing, maka merek selalu memiliki keunikan yang relatif sukar dijiplak. Maka inilah yang disebut sebagai keunggulan kompetitif berkelanjutan. Dengan merek yang dapat mewakili produk dalam arti mampu memberi persepsi yang positif terhadap produk, diharapkan mampu meraih dan mempertahankan loyalitas merek.

Pengusaha dalam negeri yang memproduksi produk dengan merek lokal dihadapkan pada kondisi persaingan yang ketat mengahadapi merek asing yang berbondong-bondong masuk ke Indonesia. Fenomena ini menuntut pengusaha untuk mempertimbangkan masalah pemberian merek produknya. Sariayu sebagai salah satu perusahaan asli Indonesia yang tetap mempertahankan merek lokal dalam menghadapi persaingan bisnis baik di dalam negeri maupun di luar negeri.

Sikap biasanya memainkan peranan utama dalam membentuk perilaku. Dalam memutuskan merek apa yang akan dibeli, atau toko mana untuk dijadikan langganan, konsumen secara khas memilih merek atau toko yang dievaluasi secara paling menguntungkan. Mahasiswa sebagai salah satu komunitas yang mudah memberikan respon terhadap suatu merek terutama merek terkenal perlu dianalis is bagaimana sikapnya terhadap merek lokal khususnya produk kosmetik Sariayu.

\section{Masalah Penelitian}

1. Bagaimanakah gambaran sikap mahasiswa terhadap merek lokal?

2. Bagaimanakah hubungan dan pengaruh keyakinan terhadap dukungan mahasiswa terhadap merek lokal?

3. Bagaimanakah hubungan dan pengaruh kesukaan terhadap dukungan mahasiswa terhadap merek lokal? 


\section{Tujuan Penelitian}

1. Untuk mengetahui gambaran sikap konsumen terhadap merek lokal

2. Untuk mengetahui hubungan dan pengaruh keyakinan terhadap dukungan mahasiswa pada merek lokal

3. Untuk mengetahui hubungan dan pengaruh kesukaan terhadap dukungan mahasiswa pada merek lokal

\section{Kontribusi Penelitian}

1. Sebagai bahan masukan kepada perusahaan lokal, untuk berusaha membina dan meningkatkan loyalitas merek demi meraih keunggulan bersaing.

2. Sebagai bahan pertimbangan dan acuan bagi penelitian serupa dan pengembangan ilmu pemasaran.

\section{METODE PENELITIAN}

\section{Rancangan Penelitian}

Berdasarkan tujuan penelitian yang hendak dicapai, maka jenis penelitian yang digunakan adalah penelitian penjelasan (explanatory), yaitu penelitian yang menyoroti hubungan antara variabel-variabel penelitian dan menguji hipotesa yang telah dirumuskan sebelumnya. Penelitian jenis ini dipilih karena sesuai dengan tujuan penelitian, yaitu untuk menjelaskan hubungan kausal yang terjadi antara variabel-variabel yang ada dengan melakukan pengujian hipotesis.

\section{Definisi Operasional dan Skala Pengukuran}

Definisi operasional dari konsep sikap adalah salah satu komponen faktorfaktor psikologis dalam diri individu yang mempengaruhi perilaku konsumen dalam pemilihan merek produk. Pada konsep sikap mengandung tiga variabel, yaitu keyakinan konsumen, kesukaan konsumen, dan dukungan konsumen.

1. Variabel keyakinan konsumen adalah sebagai hasil dari proses pembelajaran konsumen terhadap suatu produk yang menjadi obyek.

2. Variabel kesukaan konsumen adalah perasaan konsumen terhadap produk. 
3. Variabel dukungan konsumen adalah tindakan yang dilakukan oleh konsumen setelah melalui kedua tahapan sebelumnya, yaitu tindakan untuk melakukan pembelian.

Lebih lanjut, definisi operasional dari variabel-variabel yang digunakan dalam penelitian ini terlihat pada Tabel 1.

\section{Tabel 1}

\section{Variabel dan Item}

\begin{tabular}{|c|c|}
\hline Variabel & Item \\
\hline Key akinan & $\begin{array}{l}\text { 1. Key akinan berdasarkan mutu/kualitas } \\
\text { 2. Key akinan berdasarkan atribut produk } \\
\text { 3. Key akinan berdasarkan harga } \\
\text { 4. Key akinan bahwa merek produk dapat } \\
\text { menaikkan gengsi }\end{array}$ \\
\hline Kesukaan & $\begin{array}{l}\text { 1. Kesukaan berdasarkan mutu/kualitas } \\
\text { 2. Kesukaan berdasarkan atribut } \\
\text { 3. Kesukaan berdasarkan harga } \\
\text { 4. Kesukaan bahwa merek produk mudah } \\
\text { dikenali orang lain (status) }\end{array}$ \\
\hline Dukungan & $\begin{array}{l}\text { 1. Dukungan terhadap mutu/kualitas } \\
\text { 2. Dukungan terhadap atribut } \\
\text { 3. Dukungan terhadap harga } \\
\text { 4. Dukungan terhadap rangsangan pemasaran }\end{array}$ \\
\hline
\end{tabular}

\section{Skala Pengukuran}

Pengukuran adalah pemberian nilai-nilai atau angka-angka. Dalam penelitian ini menggunakan skala pengukuran kategorik, dimana ada tiga kategori jawaban responden yaitu:

- yakin/suka/mendukung dengan skor 3

- cukup dengan skor 2

- kurang yakin/suka/mendukung dengan skor 1 


\section{Populasi dan Sampel}

\section{Populasi}

Yang merupakan satuan penelitian dalam penelitian ini adalah mahasiswa yang tinggal di kelurahan Ketawang Gede Kecamatan Lowokwaru Malang yang memakai merek kosmetik lokal Sariayu. Berdasarkan hasil sensus diketahui jumlah populasi sebanyak 150 orang. Dipilihnya satuan penelitian ini, berdasarkan sensus mereka merupakan komunitas kampus yang dalam kesehariaannya sering memperhatikan merek.

\section{Teknik Pengambilan Sampel}

Dari 150 jumlah populasi kemudian dapat ditentukan besarnya sampel dengan menggunakan rumus sebagai berikut :

$$
\mathrm{n}=\frac{\mathrm{N}}{1+\mathrm{N}(0,1)^{2}}
$$

Dimana :

$\mathrm{n}=$ ukuran sampel

$\mathrm{N}=$ ukuran populasi

e $=$ persen kelonggaran sebesar $10 \%$ atau 0,1

Jadi besarnya sampel pada penelitian ini adalah :

$$
\begin{aligned}
\mathrm{n} & =\frac{215}{1+(0,1)^{2}} \\
& =60 \text { orang }
\end{aligned}
$$

Pengambilan sampel dalam penelitian ini menggunakan metode sampel acak sederhana (simple random sampling), yaitu suatu teknik pengambilan sampel yang dilakukan sedemikian rupa tanpa pandang bulu, yang penting semua anggota populasi mempunyai kesempatan yang sama untuk mewakili anggota sampelnya. Digunakan teknik ini karena responden relatif homogen, sehingga dari besarnya sampel tersebut diperkirakan dapat mewakili populasi keseluruhan. 


\section{Instrumen Penelitian}

Instrumen yang digunakan adalah kuesioner dan pedoman wawancara yang telah diuji validitas dan reliabilitasnya.

\section{Analisis Data}

1. Untuk mengetahui gambaran sikap konsumen terhadap merek produk, digambarkan dengan sebaran responden atau distribusi frek uensi.

2. Untuk menguji hipotesis adanya hubungan antara keyakinan terhadap dukungan pada merek lokal dan hipotesis kesukaan terhadap dukungan pada merek lokal menggunakan korelasi product moment, dimana Hipotesis nol ditolak apabila nilai probabilitasnya lebih kecil dari alpha 0,05

3. Untuk menguji hipotesis adanya pengaruh antara keyakinan terhadap dukungan terhadap merek lokal dan hipotesis adanya pengaruh kesukaan terhadap dukungan terhadap merek lokal digunakan analisis regresi product moment, dimana Hipotesis nol ditolak apabila nilai probabilitasnya lebih kecil dari alpha 0,05 .

4. Semua analisis ini menggunakan software SPSS 7,5 for windows.

\section{HASIL DAN PEMBAHASAN}

\section{Gambaran sikap mahasis wa terhadap me rek lokal}

Berdasarkan hasil penelitian terhadap 60 mahasiswa pemakai produk Sari Ayu, gambaran sikap mahasiswa dapat dilihat dari tiga variabel pembentuk sikap yaitu: (1) keyakinan, (2) kesukaan dan (3) dukungan. Mahasiswa adalah mahasiswa yang cukup mempunyai pertimbangan dalam memilih merek kosmetik berdasarkan hasil pra survey diketahui bahwa sebagian besar mahasiswa menggunakan kosmetik sariayu sebagai tata rias dasar keseharian. Kosmetika sariayu adalah salah satu produk lokal yang bersaing dengan belantara merek kosmetika dari luar negeri. Oleh karena itu penelitian ini akan mengungkap seberapa jauh mahasiswa sebagai konsumen menyikapi merek lokal khususnya merek kosmetik. 
Sikap berguna bagi pemasar dalam banyak cara, misalnya sikap kerap digunakan untuk menilai keefektifan kegiatan pemasaran. Sikap dapat pula membantu mengevaluasi tindakan pemasaran sebelum dilaksanakan di dalam pasar dan juga sikap sangat berhasil dalam membentuk pangsa pasar dan memilih pangsa target. Berdasarkan pada teori yang dikemukakan Engel, Blackweel dan Miniard (1994 : 338) penelitian ini melihat sikap sebagai keseluruhan evaluasi. Evaluasi yang dimaksud meliputi, keyakinan, kesukaan dan dukungan yang diberikan oleh konsumen kosmetik merek lokal yaitu Sariayu.

Pemaparan terhadap sikap konsumen terhadap merek lokal dilakukan perindikator pembentuk variabel keyakinan konsumen terhadap merek lokal, kesukaan konsumen terhadap merek lokal dan dukungan konsumen terhadap merek lokal.

\section{Keyakinan konsumen terhadap merek lokal}

Hasil dari proses pembelajaran konsumen terhadap suatu produk yang dijadikan obyek menggambarkan keyakinan konsumen terhadap obyek tersebut (Hiam dan Schwe, 1997;220). Dalam penelitian ini keyakinan konsumen terhadap merek lokal menggambarkan keyakinan terhadap mutu, atribut, harga dan kemampuan produk menaikkan gengsi konsumen.

Berdasarkan hasil peneiltian keyakinan konsumen terhadap merek lokal digambarkan dalam grafik berikut:

Gambar 1

Grafik Sebaran Keyakinan Konsumen Terhadap Merek Lokal 


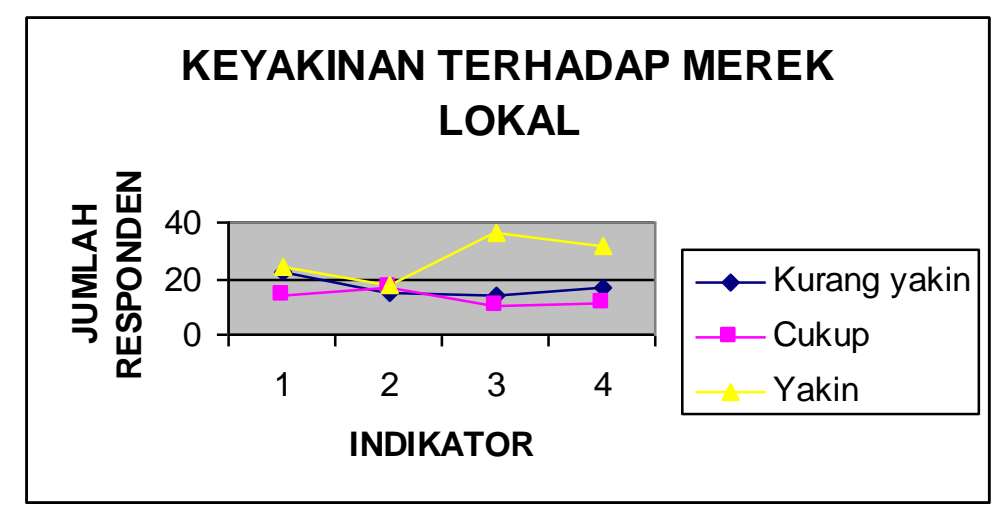

a. Keyakinan atas mutu/kualitas

Tidak begitu besar keyakinan responden terhadap mutu yang diberikan oleh merek lokal, hal ini terbukti bahwa meskipun (40\%) merasa yakin terhadap mutu/kualitas merek lokal namun $36,6 \%$ responden yang merasa kurang yakin terhadap mutu merek lokal dan 23,3\% merasa cukup. Ini menandakan bahwa ada merek selain merek lokal yang menurut responden dapat memberikan kualitas produk yang lebih bagus. b. Keyakinan atas atribut produk

Produk yang bermerek lokal ternyata memilik atribut yang dapat memberikan keyakinan yang besar bagi responden. Sebagian besar responden (60\%) merasa yakin terhadap atribut produk merek lokal, 25\% merasa kurang yakin dan 28,3\% merasa cukup. Ketika dikaji lagi tentang atribut yang dimiliki oleh kosmetika Sariayu, ternyata tidak ketinggalan dengan atribut produk merek luar. Misalnya: bedak compact sariayu dikemas dengan "bagus" sehingga konsumen tidak perlu malu membawanya ke kemapus atau ke luar rumah.

c. Keyakinan atas harga

Sebagian besar responden (60\%) merasa yakin terhadap harga merek lokal 23,3\% merasa kurang yakin dan 16,7\% merasa cukup. Hal ini desebabkan karena produk ini adalah produk lokal yang terbebas dari bea masuk dan pajak produk luar negeri sebagaimana halnya dengan produk yang bermerek luar. Sehingga harga yang ditetapkan juga lebih rendah. Selain itu perusahaan 
dalam menetapkan harga juga telah diseuaikan dengan daya beli masyarakat karena perusahaan lebih mengetahui kond isi konsumennya.

d. Keyakinan bahwa merek produk dapat menaikkan gengsi

Suatu fenomena baru yang dapat memotivasi produsen lokal untuk dapat meraih pangsa pasar dalam negeri. Karena berdasarkan hasil survey deketahui bahwa sebagian besar responden $(53,4 \%)$ merasa yakin bahwa merek produk lokal dapat menaikkan gengsi, 28,3\% merasa kurang yakin dan $18,3 \%$ merasa cukup. Ini berbeda dengan kondisi beberapa tahun yang silam bahwasanya orang akan merasa naik gengsinya kalau sudah memakai produk yang bermerek luar negeri. Ada aspek rasionalitas konsumen pada saat ini untuk mempercayai produk merek lokal.

\section{Kesukaan terhadap merk lokal}

Sikap menggambarkan perasa-an emosional menyangkut rasa suka atau tidak suka sebagai hasil dari evaluasi sebelumnya. Kotler dan Amstrong, (1996 : 157). Penelitian ini mengungkap kesukaan konsumen terhadap merek lokal dari sisi kesukaan terhadap mutu, atribut, harga dan Kesukaan bahwa merek produk merek produk mudah dikenali orang lain (status).

Berdasarkan hasil peneiltian kesukaan konsumen terhadap merek lokal digambarkan dalam grafik berikut:

\section{Gambar 2}

Grafik Sebaran Kesukaan Konsumen Terhadap Merek Lokal

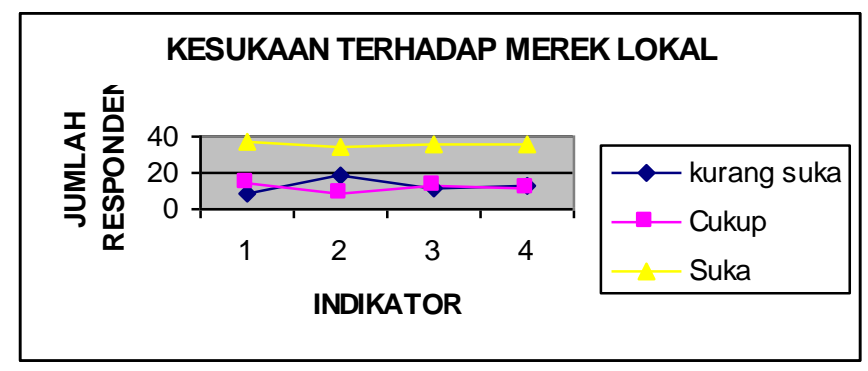


a.Kesukaan pada mutu/kualitas

Keyakinan yang rendah belum tentu diikuti dengan kesukaan yang rendah pula, hal ini terbukti meskipun keyakinan terhadap kualitas merek lokal sebesar $40 \%$ namun kesukaan konsumen terhadap mutu produk merek lokal sangat besar karena sebagian besar responden $(61,7 \%)$ merasa suka terhadap mutu/kualitas merek, 25\% merasa cukup dan 13,4\% merasa kurang suka.

b.Kesukaan pada atribut produk

Sejalan dengan keyakinan responden terhadap atribut ternyata kesukaan responden terhadap atribut produk merek lokal juga besar, hal ini ditunjukkan dengan jawaban responden yang sebagian besar (55\%) merasa suka terhadap atribut produk merek lokal 30\% merasa kurang suka dan 15\% merasa cukup. Sebagai produk yang diproduksi dengan konsep tradisional, merek dapat menyampaikan atribut-atribut tertentu, misalnya dengan merek dapat mengis yaratkan bahwa produk tersebut awet/tahan lama sesuai dengan kond isi kulit wanita Indonesia, desain yang menarik dan lain-lain.

c. Kesukaan berdasarkan harga

Tidak berbeda dengan variabel sebelumnya, sebagian besar responden $(60 \%)$ merasa suka terhadap harga merek lokal, 21,7\% merasa cukup dan $18,3 \%$ merasa kurang suka. Hal ini desebabkan karena produk ini adalah produk lokal yang terbebas dari bea masuk dan pajak produk luar negeri sebagaimana halnya dengan produk yang bermerek luar. Sehingga harga yang ditetapkan juga lebih rendah. Selain itu perusahaan dalam menetapkan harga juga telah diseuaikan dengan daya beli masyarakat karena perusahaan lebih mengetahui kond isi konsumennya.

d. Kesukaan bahwa merek produk merek produk mudah dikenali orang lain (status)

Seperti yang dikemukakakan oleh Tjiptono $\left(2000_{\mathrm{a}}\right.$ : 40) atribut awet/tahan lama dapat dicerminkan dalam manfaat fungsional seperti "saya tidak perlu membeli lagi selama beberapa tahun mendatang", sedangkan atribut desain berkualitas dapat diungkapkan dalam manfaat emosional seperti "dengan begini dapat menaikkan gengsiku". Dan merek juga menyatakan nilai-nilai 
yang dianut produsennya. Serta dalam merek terkandung pula budaya yang dianut produsennya.

Karena produsen merek lokal adalah identik dengan konsumennya maka tidaklah terlalu berlebihan kalau jawaban responden sebagian besar (60\%) merasa suka bahwa merek produk lokal dapat menaikkan gengsi 21,7\% merasa kurang yakin dan $18,3 \%$ merasa cukup.

3.Dukungan terhadap merek lokal

Engel, Blackweel dan Miniard (1994 : 338) menyatakan sikap adalah sebagai keseluruhan evaluasi. Evaluasi yang dimaksud meliputi intensitas, dukungan dan kepercayaan. Dukungan terhadap merek lokal dalam penelitian ini adalah dukungan terhadap: mutu, atribut, harga dan rangsangan pemasaran.

Berdasarkan hasil peneiltian kesukaan konsumen terhadap merek lokal digambarkan dalam grafik berikut:

Gambar 3

Grafik Sebaran Dukungan Konsumen Terhadap Merek Lokal

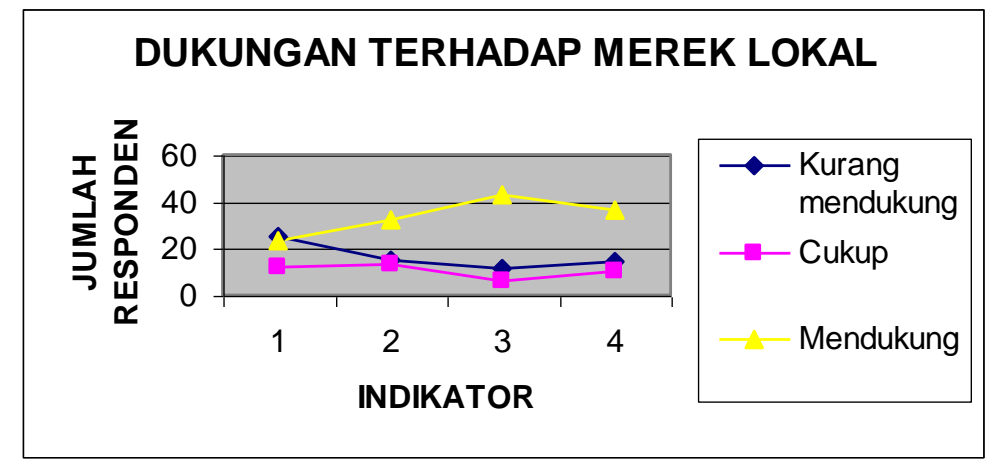

a. Dukungan terhadap mutu/kualitas

Responden yang mendukung terhadap mutu/kualitas merek sebanyak $48,47 \%$, ini hampir sama dengan responden yang kurang mendukung terhadap mutu/kualitas merek yaitu 41,6\% sedangkan 20\% kurang mendukung. Jawaban responden ini menunjukkan dukungan terhadap mutu produk merek lokal masih kurang. Hal ini menjadikan hal yang perlu ditanggapi oleh perusahaan agar meningkatkan mutu produknya. 
b. Dukungan terhadap atribut produk

Terhadap atribut produk, sebagian besar responden (53,3\%) mendukung terhadap atribut produk merek lokal $25 \%$ kurang mendukung dan $15 \%$ cukup. Ini menunjukkan bahwa selama inimerek lokal telah mampu menunjukkan usahanya dalam melakukan inovasi produk dengan upaya peningkatan atribut produknya. Sehingga konsumen memberikan dukungan yang cukup signifikan terhadap atribut produk merek lokal.

c.Dukungan terhadap harga

Dukungan konsumen terhadap harga produk merek lokal adalah besar. Sebagian besar responden $(71,7 \%)$ mendukung terhadap harga merek lokal, 18,3\% kurang mendukung dan 10\% cukup. Hal ini dapat dijadikan bahan pertimbangan bagi perusahaan dalam melakukan evaluasi terhadap kebijakan harganya, karena selama ini konsumen memberkan sikap yang positif terhadap harga produk merek lokal.

d. Dukungan terhadap rangsangan pemasaran

Rangsangan pemasaran yang diberikan produsen seperti yang dikemukakan oleh Kotler $(1995,203)$ adalah terd iri rangsangan produk, harga, saluran distribusi dan promosi. Sebagai produk lokal, Sari Ayu telah menapakkan landasan strategi pemasarannya pada konsep tradisional. Dimana perusahaan berusaha mendekati konsumen dari akar budaya seluruh nusantara. Sehingga konsumen yang merasa dirinya sebagai bagian dari manusia yang memiliki anatomi atau sifat-sifat tubuh "Indonesia" merasa sama dengan konsep yang diterapkan oleh perusahaan ini. Hal ini ditunjukkan dengan jawaban sebagian besar responden (60\%) mendukung terhadap rangsangan pemasaran $23,3 \%$ kurang mendukung dan $16,7 \%$ merasa cukup.

\section{Hubungan dan Pengaruh keyakinan pada merek lokal dengan dukungan terhadap me rek lokal}

Untuk menguji hipotesis yang diajukan, digunakan analisis korelasi dan regresi. Hasil uji regresi ditunjukkan dalam uraian berikut. 
1. Hubungan keyakinan pada merek lokal dengan dukungan terhadap merek lokal

Berdasarkan uji korelasi product momen pearson diketahui koefisien korelasi (r) sebesar 0,712 dan nilai probabilitas (p) sebesar 0,000 atau lebih kecil dari alpha 0,05. Sehingga keputusan yang diberikan adalah Ho ditolak atau terdapat hubungan yang nyata antara keyakinan pada merek lokal dengan dukungan terhadap merek lokal. Besarnya hubungan adalah hubungan yang kuat $(\mathrm{r}=0,712)$. Seperti yang ditunjukkan dalam tabel 2.

Tabel 2. Hubungan keyakinan pada merek lokal dengan dukungan terhadap merek lokal

\begin{tabular}{l|cc}
\hline & Nilai r & $\mathrm{p}$ \\
\hline Hubungan keyakinan terhadap merek lokal (X1) dengan & 0,712 & 0,000 \\
dukungan terhadap merek lokal & & \\
& & \\
\hline
\end{tabular}

2. Hubungan kesukaan terhadap merek lokal dengan dukungan terhadap merek lokal

Berdasarkan uji korelasi product momen pearson diketahui koefisien korelasi (r) sebesar 0,748 dan nilai probabilitas (p) sebesar 0,000 atau lebih kecil dari alpha 0,05. Sehingga keputusan yang diberikan adalah Ho ditolak atau terdapat hubungan yang nyata antara kesukaan terhadap merek lokal dengan dukungan terhadap merek lokal. Besarnya hubungan adalah hubungan yang kuat $(\mathrm{r}=0,748)$. Seperti yang ditunjukkan dalam tabel 3 .

Tabel3. Hubungan kesukaan terhadap merek lokal dengan dukungan terhadap merek lokal

\begin{tabular}{l|cc}
\hline & Nilai r & $\mathrm{p}$ \\
\hline Hubungan kesukaan terhadap merek lokal (X1) & 0,748 & 0,000 \\
dengan dukungan terhadap merek lokal & & \\
\hline
\end{tabular}


3. Pengaruh keyakinan terhadap merek lokal dengan dukungan terhadap merek lokal

Berdasarkan hasil analisis regresi berganda diketahui bahwa nilai probabilitas (p) sebesar 0,002 atau lebih kecil dari alpha 0,05. Sehingga keputusan yang diberikan adalah Ho ditolak atau keyakinan terhadap merek lokal berpengaruh positif terhadap dukungan terhadap merek lokal. Seperti yang ditunjukkan dalam tabel 4.

Tabel 4. Pengaruh keyakinan terhadap dukungan pada merek lokal

\begin{tabular}{c|ccccc}
\hline $\begin{array}{c}\text { Variabel } \\
\text { bebas }\end{array}$ & $\begin{array}{c}\text { Variabel } \\
\text { tergantung }\end{array}$ & $\begin{array}{c}\text { Koefisien } \\
\text { regresi }\end{array}$ & T hitung & Sig t & $\begin{array}{c}\text { Keputusan } \\
\text { Ho }\end{array}$ \\
\hline $\mathrm{X} 1$ & $\mathrm{Y}$ & 0,331 & 3,306 & 0,002 & Ditolak \\
\hline
\end{tabular}

Sumber: Data diolah

4. Pengaruh kesukaan terhadap merek lokal dengan dukungan terhadap merek lokal

Berdasarkan hasil analisis regresi berganda diketahui bahwa nilai probabilitas (p) sebesar 0,000 atau lebih kecil dari alpha 0,05. Sehingga keputusan yang diberikan adalah Ho ditolak atau kesukaan terhadap merek lokal berpengaruh positif terhadap dukungan terhadap merek lokal. Seperti yang ditunjukkan dalam tabel 5 di bawah ini.

Tabe15. Pengaruh kesukaan terhadap merek lokal dengan dukungan terhadap merek lokal

\begin{tabular}{c|ccccc}
\hline $\begin{array}{c}\text { Variabel } \\
\text { bebas }\end{array}$ & $\begin{array}{c}\text { Variabel } \\
\text { tergantung }\end{array}$ & $\begin{array}{c}\text { Koefisien } \\
\text { regresi }\end{array}$ & T hitung & Sig t & Keputusan Ho \\
\hline $\mathrm{X} 2$ & $\mathrm{Y}$ & 0,531 & 4,347 & 0,000 & Ditolak \\
\hline
\end{tabular}




\section{KESIMPULAN DAN SARAN}

\section{Kesimpulan}

1. Merek memegang peranan yang signifikan. Merek bukanlah sekedar nama yang menempel pada produk. Dalam kondisi banyak produk dan derasnya informasi seperti saat ini, konsumen pertama kali akan mengingat merek produk, bukan produsennya.

2. Banyaknya produk luar yang datang ke Indonesia menuntut sariayu yang memekai merek lokal untuk mempertahankan citra mereknya sehingga menempati posisi yang mapan pada benak konsumennya baik konsumen dalam negeri, konsumen luar negeri yang serumpun misalnya: Asia tenggara atau bahkan konsumen luar.

3. Sikap berguna bagi pemasar dalam banyak cara, misalnya sikap kerap digunakan untuk menilai keefektifan kegiatan pemasaran. Sikap dapat pula membantu mengevaluasi tindakan pemasaran sebelum dilak sanakan di dalam pasar dan juga sikap sangat berhasil dalam membentuk pangsa pasar dan memilih pangsa target. Sikap biasanya memainkan peranan utama dalam membentuk perilaku. Mahasiswa sebagai salah satu komunitas yang mudah memberikan respon terhadap suatu merek terutama merek terkenal, dalam penelitian ini dilihat bagaimana mereka menyatakan sikap mereka terhadap merek lokal yang dilihat dari keyakinan, kesukaan dan dukungannya terhadap merk lokal.

4. Dalam penelitian ini diketahui bahwa merek tidak hanya sekedar berfungsi sebagai pembeda, lebih dari itu merek bisa berfungsi sebagai identifikasi diri bahkan juga bisa sebagai cerminan kepribadian yang bisa muncul ketika konsumen menggunakan produk dari merek tersebut.

5. Berdasarkan hasil uji hipotesis diketahui bahwa kesukaan terhadap merek lokal berhubungan dan berpengaruh positif terhadap dukungan terhadap merek lokal. Serta keyakinan terhadap merek lokal berhubungan dan berpengaruh positif terhadap dukungan terhadap merek lokal. 


\section{Saran}

1. Perusahaan yang ingin bertahan lama di pasar, sebaiknya mengalokasikan biaya untuk pembentukan merek. Hal ini karena dengan memiliki merek yang kuat dan dikenal luas oleh konsumen merupakan investasi jangka panjang bagi perusahaan.

2. Perusahaan lokal perlu mempertahankan citra mereknya sehingga menempati posisi yang mapan pada benak konsumennya baik konsumen dalam negeri, konsumen luar negeri yang serumpun misalnya: Asia tenggara atau bahkan konsumen di luar itu.

\section{DAFTAR PUSTAKA}

Kotler, Philip, 1992, Manajemen Pemasaran: Analisis, Perencanaan dan Pengendalian, edisi keenam, Diterjemahkan oleh Jaka Wasana, Jilid I, Penerbit Erlangga, Jakarta.

Schoell, William F., and Joseph P. Guiltinan, 1992, Marketing Contemporary Concepts and Practices, Allyn and Bacon, USA.

Swastha, Basu, dan T.Hani Handoko, 1987, Pemasaran: Analisa Perilaku Konsumen, Edisi Pertama, Cetakan Kedua, Penerbit Liberty, Yogyakarta.

Tjiptono, Fandi, 1995, Strategi Pemasaran, Andi Offset, Yogyakarta

*) Tiwi Nurjannati Utami, MM., Dosen Fakultas Ekonomi Universitas Terbuka 